\title{
Banking regulation and the changing geography of off-balance sheet activities
}

\author{
Carmela D'Avino ${ }^{\mathrm{a}}$
}

This paper investigates whether the substitute compliance framework under the new US regime for over-the-counter derivatives has stimulated regulatory arbitrage. Results point to increased post-regulatory concentration in exposure in those countries in which US banks comply with local derivative regulation.

Keywords: US banks; interest rate swaps; derivatives regulation.

JEL: F33, G15, G21.

\footnotetext{
${ }^{a}$ University of East London, Royal Docks School of Business and Law, Water Lane, E15 4LZ, London, UK.

Contact email: c.davino@uel.ac.uk
} 


\section{Introduction}

In the light of the global nature of derivative markets, the regulatory framework for Over-The-Counter (OTC) swaps, contained in the Dodd-Frank Act (DFA), sets forth an extraterritorial applicability to foreign transactions involving US financial institutions. Enacted by the Commodity Futures Trading Commission (CFTC) in 2013, the Interpretive Guidance on cross-border swaps regulations allows foreign branches of US banks to comply with local regulation via a substitute compliance framework in a number of jurisdictions with broadly comparable provisions ${ }^{1}$.

This paper, focusing on the largest segment of swaps markets, that is, Interest Rate Swaps (IRS), investigates whether substitute compliance has resulted in regulatory arbitrage by foreign branches of US banks, tilting the playing field in favor of those countries in which the framework is available. Lagged implementation timing and/or marginally less stringent regulation in those jurisdictions where substitute compliance is available may indeed cause an increase in geographical concentration of swaps trading in favor of these latter (Artamonov, $2015)^{2}$.

Evidence on the implications of the DFA on swap markets is limited in the literature and focuses mainly on market liquidity (Benos et al., 2016; Loon and Zhong, 2016). This research is a first attempt to explore whether the DFA has stimulated cross-border regulatory arbitrage by US banks ${ }^{3}$.

The investigation is based on a novel dataset encompassing IRS positions of foreign branches of US banks aggregated over by host-country, contained in the Foreign Branch Report of Condition available from the Federal Financial Institutions Examination Council (FFIEC030). Data is available quarterly for 23 countries over the period 2001q1-2015q3. Geographical shifts in favor of locations in which regulatory equivalence is available to EU banks featuring an analogous extraterritorial reach are also accounted for ${ }^{4}$. The IRS exposure of US banks may indeed increase in countries susceptible to witness a surge in the presence of their main competitors and counterparties, that is, EU banks, resulting from a parallel attempt to circumvent domestic regulation.

Table 1 reports post-guidance growth rates of IRS exposure of branches of US banks in selected countries. Exposure in jurisdictions with substitute compliance/equivalence for either/both US or/and EU banks have increased with notable exception of Japan featuring fullyimplemented and stricter regulation (FSB, 2014).

\footnotetext{
${ }^{1}$ Applicable from December-end 2013, the interpretative guidance is a not-binding policy statement indicating intentions of forthcoming legislation. The CFTC establishes regulatory comparability of foreign jurisdictions.

${ }^{2}$ See FSB (2014) for cross-country progress in OTC reforms.

${ }^{3}$ Research on cross-border regulatory arbitrage by banks is well-documented (Acharya et al., 2009; CarboValverde et al., 2012; Houston et al. 2012).

${ }^{4}$ See the European Market Infrastructure Regulation.
} 
Table 1: IRS exposure by host country, \% 2014-2015

\begin{tabular}{|l|c|c|}
\hline & $\%$ & Substitute Compliance/Equivalence? \\
\hline Australia & 12 & US,EU \\
Canada & 42 & US,EU \\
England & -19 & US \\
Hong Kong & 36 & US,EU \\
Japan & -25 & US,EU \\
Singapore & 32 & EU \\
South Korea & 18 & EU \\
South Africa & 6 & EU \\
Switzerland & 63 & US,EU \\
\hline Taiwan & -37 & \\
Bahamas & -48 & \\
Thailand & -3 & \\
China & -20 & \\
Philippines & -16 & \\
\hline
\end{tabular}

Source: FFIEC030.

\section{Empirical analysis}

The baseline model is:

$$
I R S_{i, t}=\theta_{s}\left(D_{S}^{S C} * T R_{c}\right)+\sum_{k=1}^{K} X_{k, i, t}+\gamma_{i}+\varepsilon_{i, t}
$$

$I R S_{i, t}$ is the ratio of IRS (notional amounts) to assets of branches located in host-country $i$, $i=1, \ldots, 23$. $D_{S}^{S C}$ accounts for host country groupings, captured by $s$ dummies, $s=1, \ldots, S$ allowing to assess geographical shifts either away from those locations with tighter regulations, such as European countries and Japan, or towards those jurisdictions in which substitute compliance/equivalence is available. European countries are captured by the dummy Europe; a dummy is also used for England. DUSnoEU contains countries, other than European, in which substitute compliance is available to branches of US banks. $D E U$ identifies those locations, other than the US, in which regulatory equivalence is available to EU banks ${ }^{5}$. Country dummies are also considered without Japan in the following identifiers: DUSnoJP and DEUnoJP. See Table 2 for details.

\footnotetext{
${ }^{5}$ Including those countries granted equivalence by the European Commission in both 2014 and 2015.
} 
Table 2: Country dummies

\begin{tabular}{|lllll|}
\hline Europe & DUSnoEU & DUSnoJP & DEU & DEUnoJP \\
\hline Italy & Australia & Australia & Australia & Australia \\
Belgium & Hong Kong & Hong Kong & Hong Kong & Hong Kong \\
England & Canada & Canada & Canada & Canada \\
Germany & Japan & Italy & Japan & Singapore \\
France & & Belgium & Singapore & Republic of Korea \\
& & England & Republic of Korea & South Africa \\
& & Germany & South Africa & \\
& & France & & \\
\hline
\end{tabular}

$T R_{c}, \mathrm{c}=\mathrm{US}, \mathrm{EU}$ are time dummy variables, capturing the timing of the extraterritorial applicability of derivative regulation in the US (2014q1-2015q3) and in the EU (2014q4$2015 q 3) \cdot \gamma_{i}$ is a fixed-effect that captures unobserved host-country specific variables, such as differences in regulatory environment. Fixed-time period dummies are also included in the regression (unreported) to account for common time-varying effects on IRS exposures across the panel.

$X_{i, t}$ contains $\mathrm{k}=1, \ldots, \mathrm{K}$ control variables. The choice of the location of IRS trading of branches may not be necessarily driven by local economic conditions as counterparties are often located in third countries. Albeit a given jurisdiction's macroeconomic stability and favourable regulation can stimulate local off-balance sheet activities, financial markets depth, sophistication and openness can also explain the locational choice of IRS trading. Financial openness (Openness $s_{i t}$ ) is proxied by host location $i$ 's cross-border assets plus liabilities vis-àvis reporting banks as a share of host county's GDP. Outstanding derivative positions on resident counterparties as a share of GDP (derivatives ${ }_{i t}$ ) proxy for local financial development and sophistication. Inflation rates proxy for macroeconomic stability in $i$ (inflation it $_{i}$ ) and the $\log$ of assets of branches in $i\left(\right.$ size $\left._{i t}\right)$ controls for the relative importance of on-balance sheet activities. IRS exposure of banks arises primarily from market-making/dealing and interest rate risk management. Interest rate risk at the host-country level capturing the latter is proxied by the absolute value of one minus the loans-to-deposit ratio (IRrisk).

\section{Results}

Table 3 presents the regression estimates of (1) for different specifications. The coefficient of Europe ${ }^{*} \operatorname{Tr} U S$ in column (1) shows that in the US post-regulation era the IRS exposure of foreign branches of US banks in Europe has declined 6.5\% more than in other locations. This fall is particularly important for branches located in England whose IRS exposure was $22 \%$ lower than elsewhere over the same period, as reported in column (2).

Specifications in columns (3)-(8) capture those locations in which a framework of substitute compliance/equivalence is available to either US and/or EU banks. Column (4) considers exclusively the pre-guidance period (i.e. $\operatorname{Tr} U S=0$ ) in order to test whether IRS exposure of US banks had not been growing at a faster rate before 2014 in those countries in which substitute compliance was available. Column (8) considers the marginal effects on IRS 
exposure in the subgroup of countries, other than Japan, in which both US and European banks can rely on local derivative regulations, i.e. in Australia, Hong Kong and Canada.

The estimated coefficients of the different country interaction dummies in specifications (3)-(8) are all positive and strongly significant. However, when comparing preand post-guidance increase in IRS exposure in those countries with substitute compliance in relation to other foreign locations (DUSnoEU definition, columns 3 and 4), post-guidance levels were significantly higher. Overall, evidence points to a more pronounced, i.e. when compared to other locations, post-regulatory increase in IRS exposure of branches of US banks located in those countries in which substitute compliance/equivalence is either available to them or to branches of EU banks. This geographical shift is particularly important in those countries, other than Japan, in which equivalence is available to EU banks, as reported in column (7), in which IRS exposure has increased 9\% more than elsewhere since early 2014. This evidence suggests a swift response of US banks to move a large part of their off-balance sheet activities to those countries more susceptible to accommodate a higher volume of swap trading by their major competitors and counterparties. The subset of jurisdictions, other than Japan, in which branches of both EU and US banks can comply with local OTC regulation depict the highest post-guidance increase in IRS exposure: about $9.4 \%$ higher than elsewhere (column 8).

The estimated coefficients of the control variables reveal that macroeconomic stability is an important determinant of the location of IRS exposure by foreign branches of US banks. The negative and strongly significant coefficient of on-balance sheet assets (in logs), i.e. size $e_{i, t}$, uncovers a geographical polarization of on and off-balance sheet activities of branches of US banks. The nonsignificant coefficient of IRrisk reflects the fact that IRS exposure is largely due to dealing and market-making rather than to insure from the interest rate risk that arises from local activities.

\section{Conclusions}

The 2007-09 global financial crisis has uncovered the potential threats to domestic financial stability posed by excessive risk taken by foreign offices of global banks. The extraterritorial clause contained in the OTC swaps regulation, set out in the DFA, reflects the intent of US regulators to prevent further large scale bailouts such as that of American International Group in 2008 caused by the excessive swaps exposure by its London office. While the new regulatory framework aims to discourage geographical concentration of risk by US banks, loopholes arising from substitute compliance frameworks available for US banks may create new geographical hubs for swaps trading. The findings in this paper point to significant relocation of IRS exposure of branches of US global banks away from traditional locations, such as England, and in favor of those countries in which US and/or EU banks can comply with local OTC derivatives market regulation. This evidence points to the existence of loopholes in international regulatory systems arising from technical nuances. 
Table 3 Panel regression

Dependent variable: IRS notional amounts to assets in time t

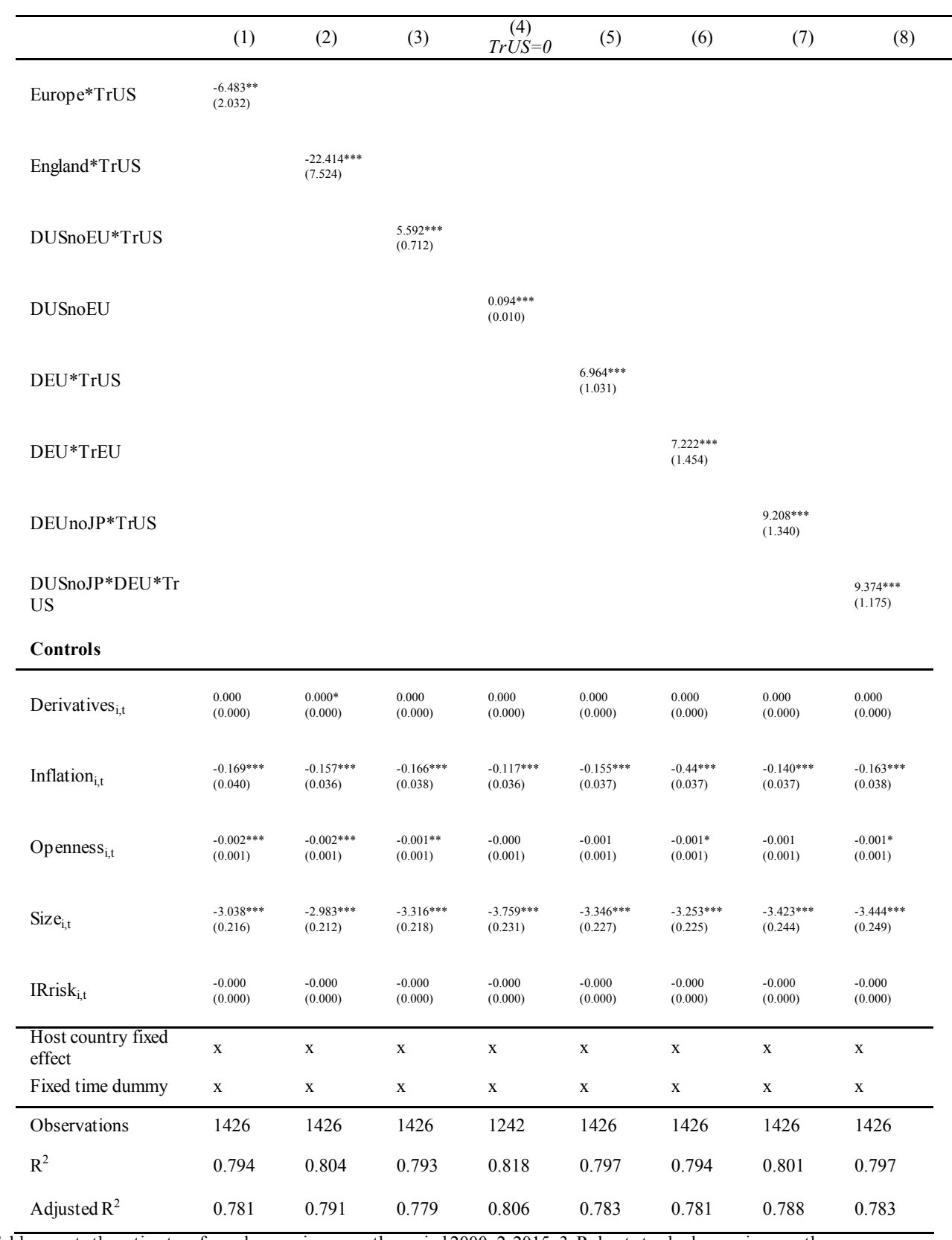

Notes: This Table reports the estimates of panel regressions over the period 2000q2-2015q3. Robust standard errors in parentheses. $* * *, * *, *$ refer to $1 \%, 5 \%$ and $10 \%$ significance levels, respectively. 


\section{References}

Acharya, V., Wachtel, P., Walter, I., 2009. International alignment of financial sector regulation. Finan. Markets, Inst. Instruments. 18(2), 188-190.

Artamonov, A., 2015. Cross-border application of OTC derivatives rules: revisiting the substituted compliance approach. Journal of Financial Regulation. 206-225.

Benos E., Payne, R., Vasios, M., 2016. Centralized trading, transparency and interest rate swap market liquidity: evidence from the implementation of the Dodd-Frank Act. Bank of England working papers 580, Bank of England.

Carbo-Valverde, S., Kane, E., Rodriguez-Fernandez, F., 2012. Regulatory arbitrage in crossborder banking mergers within the EU. J Money Credit Bank, 44(8), 1609-1629.

Financial Stability Board, FSB, 2014. OTC derivatives market reforms: Eight progress report on implementation. http://www.fsb.org/wp-content/uploads/r_141107.pdf Accessed 01July 2016

Houston, J., Lin, C., Ma, Y., 2012. Regulatory arbitrage and international bank flows. J. Finance, 67(5), 1845-1895.

Loon, Y., Zhong, Z., 2016. Does Dodd-Frank affect OTC transaction costs and liquidity? Evidence from real-time CDS trade reports. J. Financ. Econ, 119(3), 645-672. 